\title{
Androgen receptor non-nuclear regulation of prostate cancer cell invasion mediated by Src and matriptase
}

\author{
Jelani C. Zarif ${ }^{1,2}$, Laura E. Lamb ${ }^{3}$, Veronique V. Schulz ${ }^{1}$, Eric A. Nollet ${ }^{1,4}$, Cindy K. \\ Miranti ${ }^{1}$ \\ ${ }^{1}$ Laboratory of Integrin Signaling and Tumorigenesis, Van Andel Research Institute, Grand Rapids, MI 49503, USA \\ ${ }^{2}$ Cell and Molecular Biology Program, Michigan State University, East Lansing, MI 48824, USA \\ ${ }^{3}$ Department of Urology, Beaumont Health System - Research Institute, Royal Oak, MI 48073, USA \\ ${ }^{4}$ Van Andel Institute Graduate School, Grand Rapids, MI 49503, USA \\ Correspondence to: \\ Cindy K. Miranti, e-mail: cindy.miranti@vai.org \\ Keywords: prostate cancer, nongenomic AR signaling, Src, metastasis, castration-resistant
}

Received: July 09, $2014 \quad$ Accepted: January 08, $2015 \quad$ Published: January 29, 2015

\section{ABSTRACT}

Castration-resistant prostate cancers still depend on nuclear androgen receptor (AR) function despite their lack of dependence on exogenous androgen. Second generation anti-androgen therapies are more efficient at blocking nuclear AR; however resistant tumors still develop. Recent studies indicate Src is highly active in these resistant tumors. By manipulating AR activity in several different prostate cancer cell lines through RNAi, drug treatment, and the use of a nuclear-deficient AR mutant, we demonstrate that androgen acting on cytoplasmic AR rapidly stimulates Src tyrosine kinase via a non-genomic mechanism. Cytoplasmic AR, acting through Src enhances laminin integrin-dependent invasion. Active Matriptase, which cleaves laminin, is elevated within minutes after androgen stimulation, and is subsequently shed into the medium. Matriptase activation and shedding induced by cytoplasmic AR is dependent on Src. Concomitantly, CDCP1/gp140, a Matriptase and Src substrate that controls integrin-based migration, is activated. However, only inhibition of Matriptase, but not CDCP1, suppresses the AR/Src-dependent increase in invasion. Matriptase, present in conditioned medium from AR-stimulated cells, is sufficient to enhance invasion in the absence of androgen. Thus, invasion is stimulated by a rapid but sustained increase in Src activity, mediated non-genomically by cytoplasmic AR, leading to rapid activation and shedding of the laminin protease Matriptase.

\section{INTRODUCTION}

The survival of malignant tumors arising from the prostate gland is dependent on the androgen receptor (AR), a classical nuclear steroid receptor that binds androgen and activates gene transcription [1,2]. This dependence on androgen is exploited therapeutically; patients presenting with metastatic disease are treated with anti-androgen therapies that effectively lower circulating androgen levels and cause tumor regression. However, patients typically relapse within one to two years and develop castration-resistant disease in which the tumors no longer respond to androgen ablation therapy [3]. Nonetheless, AR itself is still critical as demonstrated by its retention, mutation, and amplification in resistant disease $[4,5]$. The critical role of AR is further supported by the fact that more potent second generation antiandrogen therapies are able to extend patient survival. Unfortunately, even these therapies are still not curative.

Studies with the new anti-androgen agent MDV3100 (enzalutamide) indicate one of the ways it inactivates AR nuclear activity in the tumor cells is by preventing nuclear translocation, thus retaining a significant amount of AR the cytoplasm [6, 7]. Several steroid receptors, including $\mathrm{AR}$, are reported to have non-nuclear (aka non-genomic) signaling functions in the cytoplasm independent of their transcriptional activity [8-13]. These non-nuclear signaling mechanisms are associated with rapid responses (within minutes) of steroid stimulation. One common target of steroid receptor nongenomic signaling is the 
non-receptor tyrosine kinase, Src [14-17]. Activated Src correlates with resistance to MDV3100 (enzalutamide) in castration-resistant patients [18]. Thus, it is necessary to understand how Src promotes castration-resistant disease.

Src is a prototypic member of the non-receptor protein tyrosine kinase family (SFK) up-regulated or hyper-activated in a high percentage of human cancers $[19,20]$. SFK activation and signaling is highly associated with bone metastasis in breast and prostate cancer [21, 22]. Inhibition of Src and Lyn with dasatinib decreased prostate cancer growth and lymph node metastasis in AR-independent and -dependent xenograft models [23]. In vitro, Lyn was required primarily for tumor cell growth, while Src was responsible for promoting cell migration. The specific effect of Src on migration is not surprising given that many Src substrates, such as FAK, Cas, and cortactin, are intimately involved in promoting cell motility through integrin-mediated adhesion to extracellular matrices $[17,21]$.

Src is activated nongenomically in cells by progesterone receptor (PR), estrogen receptor (ER), and $\mathrm{AR}$, via interactions between the Src SH3 domain and a PXXP-containing scaffold protein, NMAR/PELP, that binds steroid receptors via LXXLL motifs. Alternatively, the Src SH3 domain binds directly to the PXXP motif in AR or PR $[14,15]$. Assembly of Src-containing ER and AR complexes activates MAPK signaling to stimulate cell proliferation and castration-resistance [24, 25]. ER, acting through Src to activate ILK1 was recently shown to be responsible for enhancing breast cancer invasion and metastasis [26]. While several studies independently linked increased invasion and metastasis with elevated AR or Src activity $[27,28]$, the specific role of cytoplasmic AR signaling via Src to promote prostate cancer migration and invasion was not reported.

We previously demonstrated that AR activation in prostate cancer cells increases integrin $\alpha 6 \beta 1$ transcription and expression [29, 30]. During that study, we also observed that $\mathrm{AR}$ activation induced morphological changes in the cells. We hypothesized that AR contributes to prostate cancer cell migration and invasion, possibly through stimulation of integrin $\alpha 6 \beta 1$ transcription. As described herein, we identified an AR-dependent non-nuclear signaling pathway, independent of integrin $\alpha 6 \beta 1$ transcription, leading to Src activation and subsequent cleavage and shedding of Matriptase, required for prostate cancer invasion.

\section{RESULTS}

\section{AR stimulation alters cell shape, migration, and invasion via laminin integrins}

Previously, we generated PC3 cells stably expressing wild type AR [29]. We demonstrated AR was constitutively nuclear localized and activated in PC3-AR cells as measured by immunofluorescent staining and PSA expression. During those studies we observed marked changes in cell morphology in the AR-expressing cells compared to the parental vector cells (PC3-Puro). To quantify these differences, PC3-Puro and PC3-AR cells were plated on laminin and immunostained to visualize actin structures. There was a marked increase in cell spreading on laminin by the AR-expressing cells compared to the vector cells (Figure 1A), which was accompanied by an 8 -fold increase in filopodial structures (Figure 1B). The observed increase in filopodia formation specifically in PC3-AR cells correlated with a 22-fold increase in Boyden chamber migration (Figure 1C) as well as a 3- to 4-fold increase in Matrigel invasion (Figure 1D) compared to PC3-Puro vector cells. Furthermore, inhibiting AR activity with Casodex or RU486 attenuated the AR-specific increase in Matrigel invasion (Figure 1D). Complementary experiments were conducted using LNCaP and C4-2 cells which express endogenous AR. In LNCaP and C4-2 cells, stimulation of AR with R1881 increased Matrigel invasion 3- and 2.4fold respectively (Figure 1E). Conversely, AR suppression using siRNA decreased Matrigel invasion stimulated by R1881 (Figure 1F). We previously demonstrated that AR transcriptionally induces integrin $\alpha 6 \beta 1$ expression [29]. However, blocking integrin $\alpha 6$ or $\alpha 3$ expression alone did not block invasion (not shown). Depletion of both laminin integrins, $\alpha 3$ and $\alpha 6$, was required to suppress Matrigel invasion 4-fold (Figure 1G). Thus AR promotes the migration and invasion of prostate tumor cells through Matrigel via either of two laminin-specific integrins.

\section{AR stimulates Src activation}

Src is a major effector of cell spreading, migration, and invasion [19, 20]. Therefore we investigated Src activation and expression in the PC3-Puro and PC3AR cells. We found elevated Src expression as well as increased Src activity in PC3-AR cells as measured by anti-phospho-[Y $\left.{ }^{416}\right]$-Src antibody (Figure 2A). Inhibiting AR expression in PC3-AR clones with siRNA decreased Src activation, but not total Src (Figure 2B) demonstrating AR regulates Src activation but not its expression. Stimulating LNCaP or C4-2 cells with R1881 for twenty minutes was sufficient to increase Src activation, but did not change Src expression (Figure 2C). Conversely, inhibiting AR expression with siRNA in $\mathrm{LNCaP}$ and C4-2 cells suppressed Src activation in response to R1881 (Figure 2D). Similarly, suppressing AR activation in PC3-AR cells with RU486 or Casodex suppressed Src activation (Figure 2E). Thus, AR is required for Src activation in several different prostate tumor cell lines.

Inhibiting Src with siRNA did not alter AR expression (Figure 2F) indicating Src is downstream of AR. AR stimulates integrin $\alpha 6$ [29], which could activate Src. However, inhibiting integrin $\alpha 6$ expression with siRNA did not change Src activity or expression (Figure 2G). 

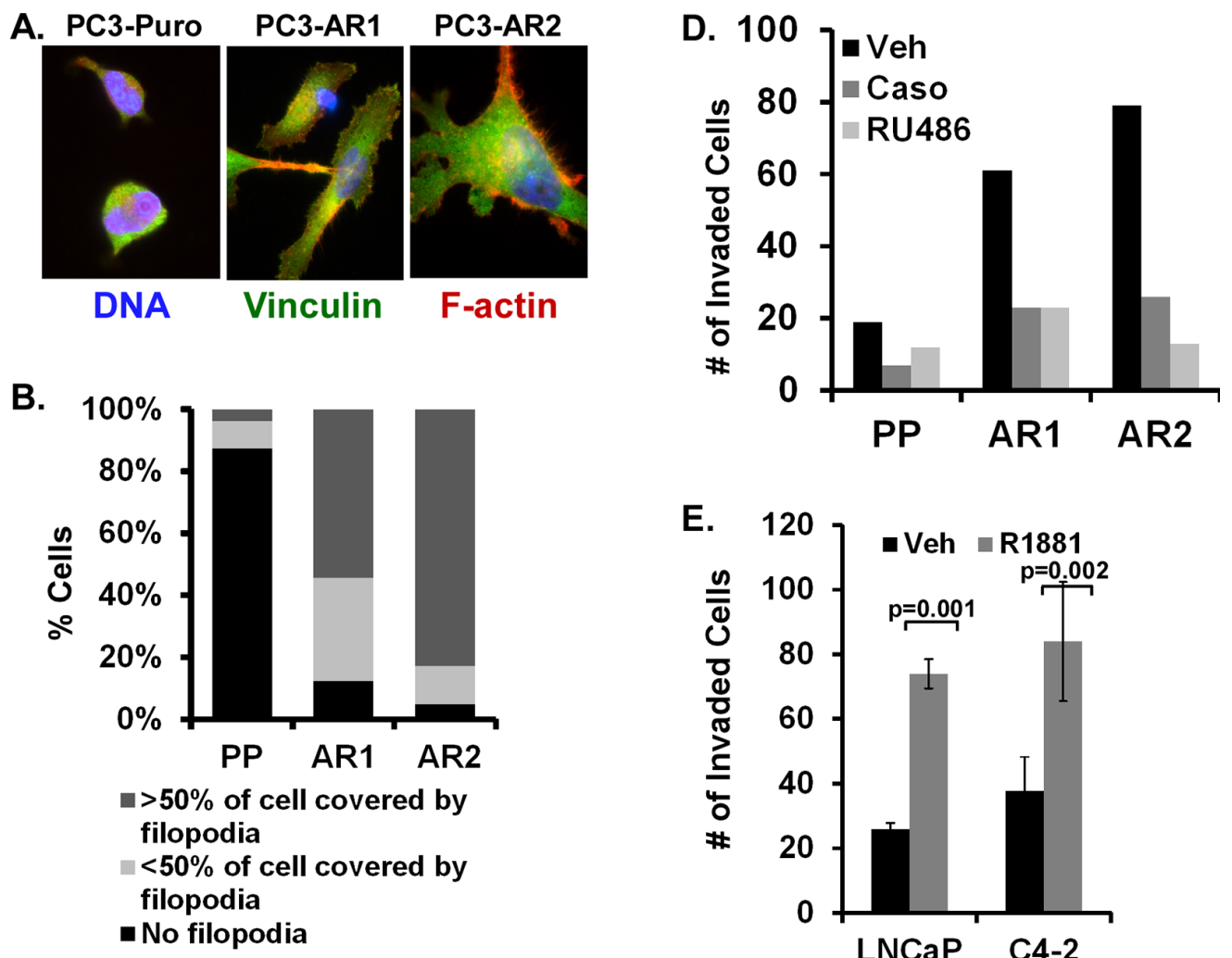

C.
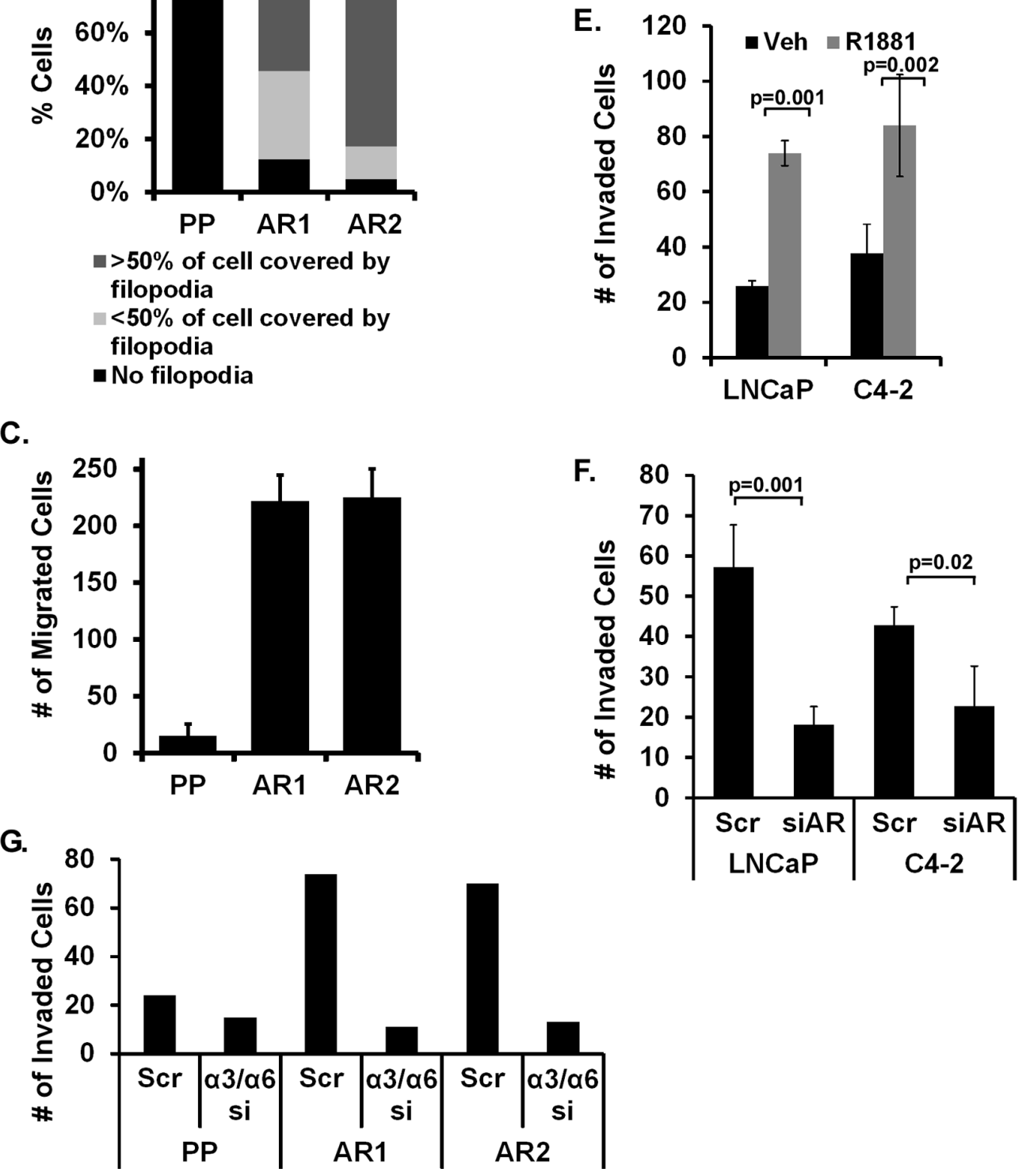

Figure 1: AR stimulation alters cell shape, migration, and invasion via laminin integrins. (A, B) Parental PC3 (Puro) and 2 PC3-AR clones (AR1 and AR2) were plated on laminin for 1 hour then (A) immunostained for vinculin (green), stained for F-actin with phalloidin (red), and counterstained with Hoecsht (blue). (B) Percentage of cells with filopodia was quantified. (C) Migration on laminincoated Boyden chamber inserts was quantified in PC3-Puro (PP) versus PC3-AR clones. (D) Extent of invasion through Matrigel-coated Boyden chambers was quantified following treatment of PC3 (Puro) or PC3-AR clones with ethanol (Veh), 10 nM Casodex (Caso), or 10

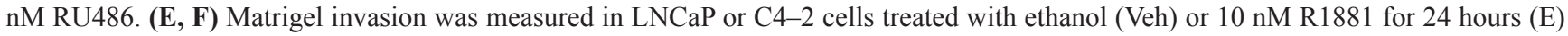
without or (F) with scrambled siRNA (Scrm) or AR-specific siRNA (siAR). (G) Matrigel invasion by PC3-Puro (PP) or PC3-AR clones treated with scrambled (Scr) or combined integrin $\alpha 3$ and $\alpha 6$ siRNA (a3/a6) was measured. 
A.

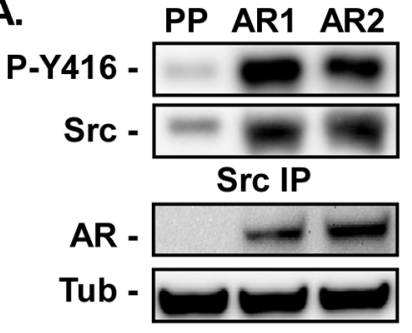

C.

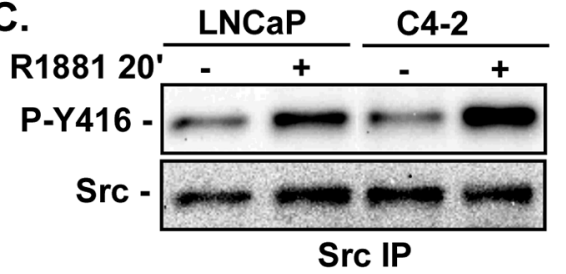

AR -

Tub -

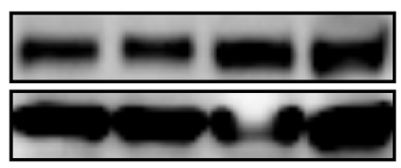

E.

PC3-AR1

Veh RU Caso

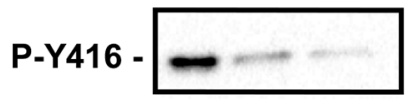

Src -

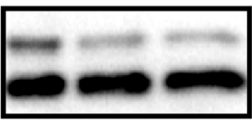

Src IP

G.

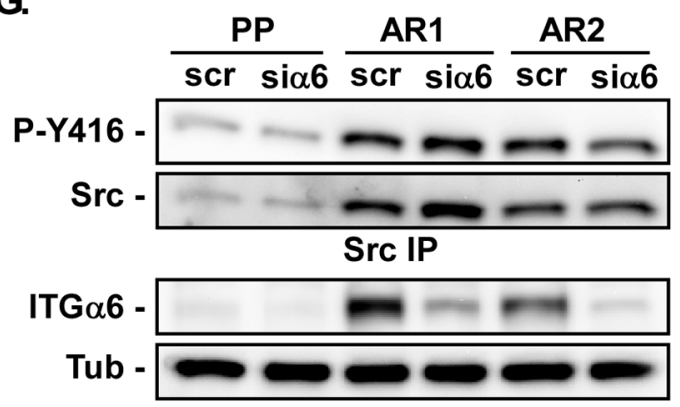

B.

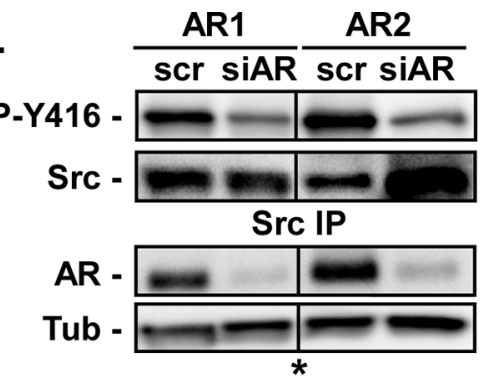

D.

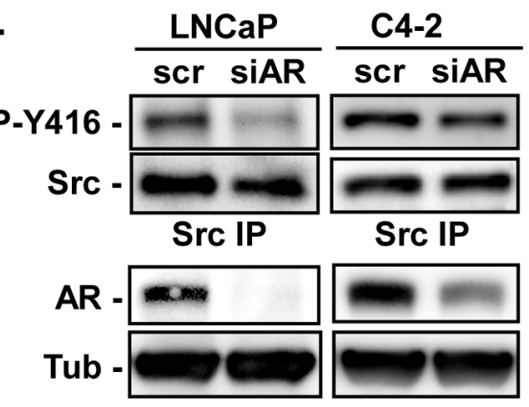

F.

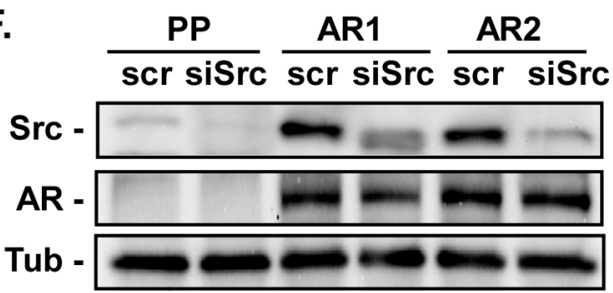

Figure 2: AR stimulates Src activation. (A, B) Src activation and expression in PC3-Puro (PP) or PC3-AR clones (AR1/AR2) was measured by immunoblotting of Src immunoprecipitates with anti-Y416 phospho-specific antibody or total anti-Src antibody respectively in (A) untreated cells or (B) cells treated with scrambled siRNA (scr) or AR-specific siRNA (siAR). *All samples were run on the same gel, but image was cut to remove extraneous lanes. Total levels of AR and tubulin (Tub) expression served as loading controls and were monitored by immunoblotting. (C, D) Src activation and expression was measured in LNCaP or C4-2 cells stimulated with ethanol (-) or $10 \mathrm{nM}$ R1881 for 20 minutes in (C) untreated cells or (D) cells treated with scrambled siRNA (scr) or AR-specific siRNA (siAR). (E) Src activation and expression was measured in PC3-AR1 cells treated with ethanol (Veh), $10 \mathrm{nM}$ RU486 or $10 \mathrm{nM}$ Casodex (Caso) for 24 hours. (F) Src and AR expression were measured by immunoblotting in PC3-Puro (PP) or PC3-AR clones (AR1/AR2) treated with scrambled siRNA (scr) or Src-specific siRNA (siSrc). (G) PC3-Puro (PP) or PC3-AR clones (AR1/AR2) were treated with scrambled siRNA (scr) or integrin $\alpha 6$-specific siRNA (sia6). Src activation and expression in immunoprecipitates and integrin $\alpha 6$ expression cell lysates were measured by immunoblotting. (H) Percentage of cell death was measured by trypan blue dye exclusion following adhesion to laminin. 
Src is also not involved in AR-dependent survival signaling, since suppressing Src expression with siRNA in PC3-AR clones caused no increase in cell death (Figure 2H). Treatment of PC3-Puro or PC3-AR cells with RU486 or Casodex also did not induce cell death (not shown). Thus $\mathrm{AR}$, independently of its actions on integrin $\alpha 6$ expression or cell survival, stimulates Src activity.

\section{$A R$ and Src are required for invasion}

To determine if AR-dependent stimulation of Src is responsible for the increase in invasiveness, cells were transfected with scrambled or specific siRNAs directed towards AR or Src. Inhibition of AR or Src expression attenuated PC3-AR invasion 3- to 4-fold; similar to levels seen in PC3-Puro control cells (Figure 3A). Inhibiting Src expression in $\mathrm{LNCaP}, \mathrm{C} 4-2$, or $\mathrm{VCaP}$ cells with the siRNAs or with individual independent shRNAs similarly decreased R1881-stimulated Matrigel invasion 2.5- to 3-fold (Figure 3B, 3C). To assess whether AR stimulates Src activity and invasion via a non-nuclear mechanism, Src activation was measured in PC3 cells expressing AR with a mutated nuclear localization sequence (AR $\triangle N L S$ ) or AR with a mutated ligand binding domain (AR $\triangle \mathrm{LBD}$ ) (Figure 3D). As described previously, the ARANLS mutant is cytoplasmic while the AR $\triangle \mathrm{LBD}$ mutant is predominantly nuclear, and both expressed at the same levels as wild type AR in the PC3 cell lines [29, 31, 32]. Src activity and expression were elevated in all AR-expressing mutant cell lines, similar to that seen in PC3-AR cells. Cells expressing the ARANLS mutant also displayed increased Matrigel invasiveness compared to vector control cells, which was suppressed 2.5- to 2.8-fold when Src was inhibited with siRNA (Figure 3E). However, despite elevated levels of Src expression and activity in the AR $\triangle \mathrm{LBD}$ mutants, their invasiveness was unaffected by Src inhibition (Figure 3F), indicating that AR ligand binding activity may be crucial for Src-dependent invasion. Thus, the ability of AR to promote Src-dependent invasion occurs via a non-nuclear, but ligand-dependent mechanism.

\section{AR stimulates Matriptase cleavage and its extracellular shedding via a non-nuclear mechanism}

Matrigel invasion requires proteolytic degradation of laminin substrates; therefore, we measured expression of the active form of the laminin protease Matriptase [33-35]. Matriptase is activated by autocatalytic cleavage of the $95 \mathrm{kDa}$ zymogen into a transmembrane $72 \mathrm{kDa}$ fragment tethered by a disulfide bond to the active enzymatic domain [35]. The active transmembraneassociated protein is then shed as a $\sim 60 \mathrm{kd}$ fragment tethered to the active enzyme. Thus, both the cleaved cell-associated and shed enzymes are active. PC3Puro and PC3-AR cells were stimulated with R1881 for 20,60 or 120 minutes and the amounts of cleaved cell-associated (cell lysates) and shed (conditioned medium) Matriptase were measured by immunoblotting with an antibody that recognizes the $72 \mathrm{kDa}$ transmembrane and $60 \mathrm{kd}$ shed fragments. PC3-AR cells displayed elevated levels of cleaved cell-associated Matriptase compared to PC3-Puro cells (Figure 4A). Suppression of AR in PC3AR cells using a tetracycline-inducible shRNA decreased cleaved Matriptase expression (Figure 4B). Interestingly, despite non-detectable AR expression in PC3-Puro cells, a low level of cleaved Matriptase was detectable in the medium and more was released after 2 hours of androgen stimulation. In contrast, cleaved Matriptase was constitutively shed into the medium of PC3-AR cells. PC3 cells are reported to express low, but unstable levels of AR $[36,37]$. Low levels of steroid receptors are often not sufficient to stimulate transcription, but are still capable of mediating nongenomic signaling. That androgen rapidly increases shedding of cleaved Matriptase in PC3Puro cells suggest a possible non-nuclear mechanism for Matriptase activation when AR expression is low. To test this, we measured cleaved cell-associated and shed Matriptase in PC3 cells expressing the NLS or LBD AR mutant following R1881 stimulation. PC3-AR $\triangle N L S$, but not PC3-AR $\triangle \mathrm{LBD}$, cells induced the accumulation of cleaved cell-associated and shed Matriptase within 20 minutes following androgen stimulation (Figure 4C). Thus, the AR-dependent increase in cleaved Matriptase requires ligand binding, but not nuclear activity.

In complementary experiments with $\mathrm{LNCaP}$ and C4-2 cells, Matriptase shedding was observed 24 hours after androgen stimulation (Figure 4D). Cell-associated cleaved Matriptase was elevated within twenty minutes of ligand stimulation (Figure 4E) and remained elevated for a few hours, but by 24 hours its levels decreased while shed Matriptase levels increased (Figure 4F). Thus, androgen initially stimulates Matriptase cleavage within the cell, and that cleaved Matriptase is subsequently shed into the medium. The increase in cleaved Matriptase within 20 minutes of androgen stimulation was resistant to mRNA synthesis inhibition by Actinomycin D (Figure 4G) indicating androgen stimulates this rapid Matriptase cleavage independent of transcription, further supporting a rapid nonnuclear action of AR on Matriptase. Suppressing Src activity with dasatinib or two different Src shRNAs decreased the androgen-dependent induction of Matriptase cleavage in C4-2 cells (Figure 4H, 4I). Thus, the ability of AR to induce Matriptase cleavage and shedding is dependent on Src. Altogether these data indicate AR signaling through Src via a ligand-dependent, but non-nuclear, mechanism is required to stimulate Matriptase cleavage and induce its shedding.

\section{CDCP1 activity is regulated by AR and Src}

Cub Domain Containing Protein 1 (CDCP1/gp140/ Trask) is a transmembrane glycoprotein that facilitates integrin-dependent migration and invasion and whose 

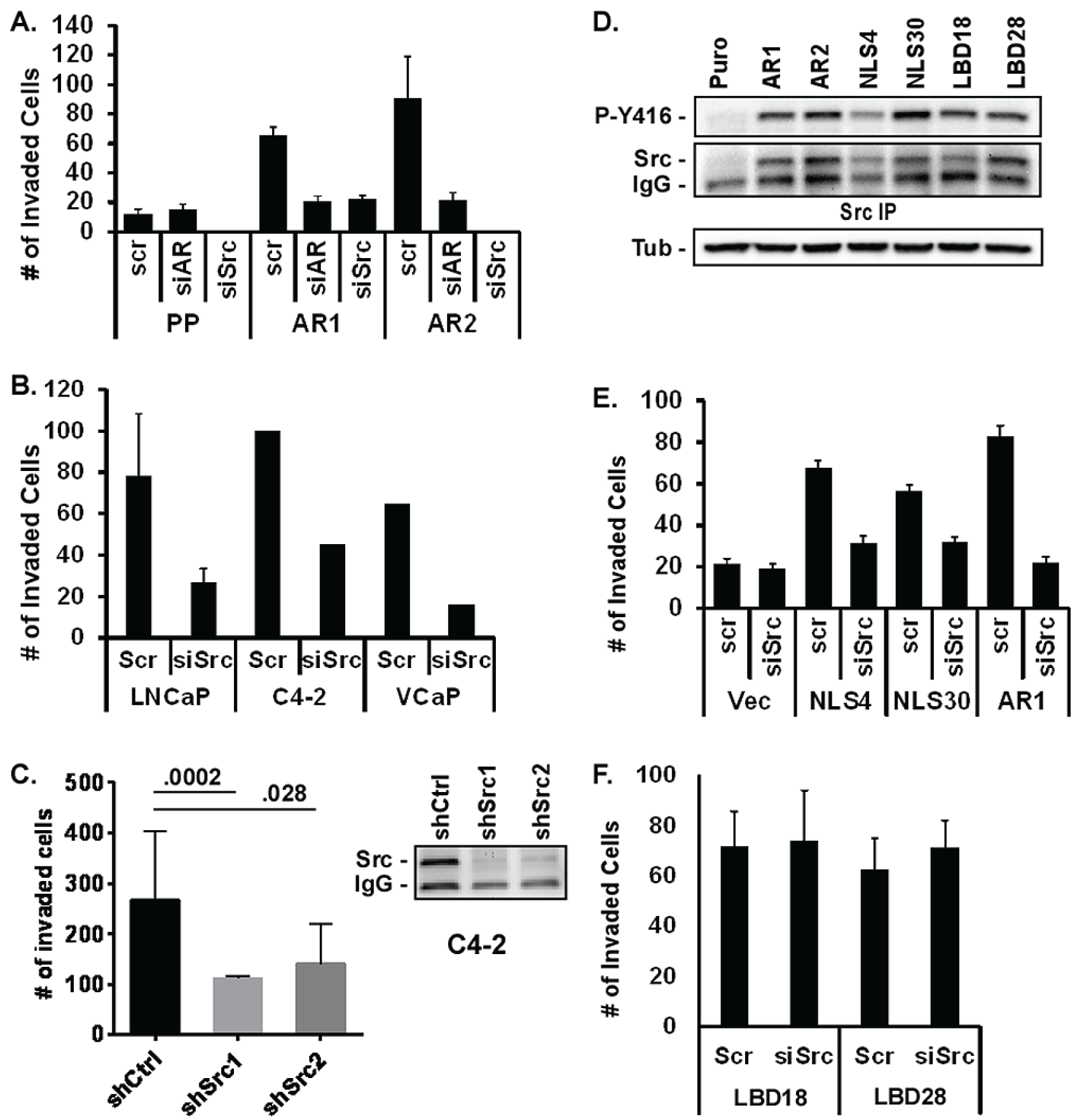

Figure 3: AR and Src are required for invasion. (A) Matrigel invasion was measured in PC3-Puro (PP) or PC3-AR clones (AR1/AR2) treated with scrambled siRNA (scr), AR-, or Src-specific siRNA (siAR, siSrc). (B, C) Matrigel invasion was measured in R1881-stimulated LNCaP, VCaP, or C4-2 cells following treatment with (B) scrambled siRNA (scr) or Src-specific siRNA (siSrc) or upon expression of (C) control shRNA (shCtrl) or two different shSrc constructs. Src levels before and after shSrc expression were measured by immunoblotting of Src immunoprecipitates. (D) Src activation and expression was measured in PC3 cell lines expressing wild type (AR1/AR2), nuclear localization deficient (NLS), or ligand binding deficient(LBD)AR mutants by immunoblotting of Src immunoprecipitates with anti-Y416 phospho-specific antibody or total anti-Src antibody respectively. (E, F) Matrigel invasion was measured in PC3 (Vec), PC3-AR1, AR-NLS, or AR-LBD clones treated with scrambled siRNA (scr) or Src-specific siRNA (siSrc).

elevated expression in primary tumors correlates with metastasis in several cancers [38]. CDCP1 is cleaved by several serine proteases, including Matriptase [39]. Full-length CDCP1 (140 kDa) and its cleaved form
$(72 \mathrm{kDa})$ are direct $\mathrm{Src}$ substrates and phosphorylation by $\mathrm{Src}$ is required for promoting cellular de-adhesion from matrix and invasion [40-42]. AR expression in PC3 cells increased the expression, cleavage, and 

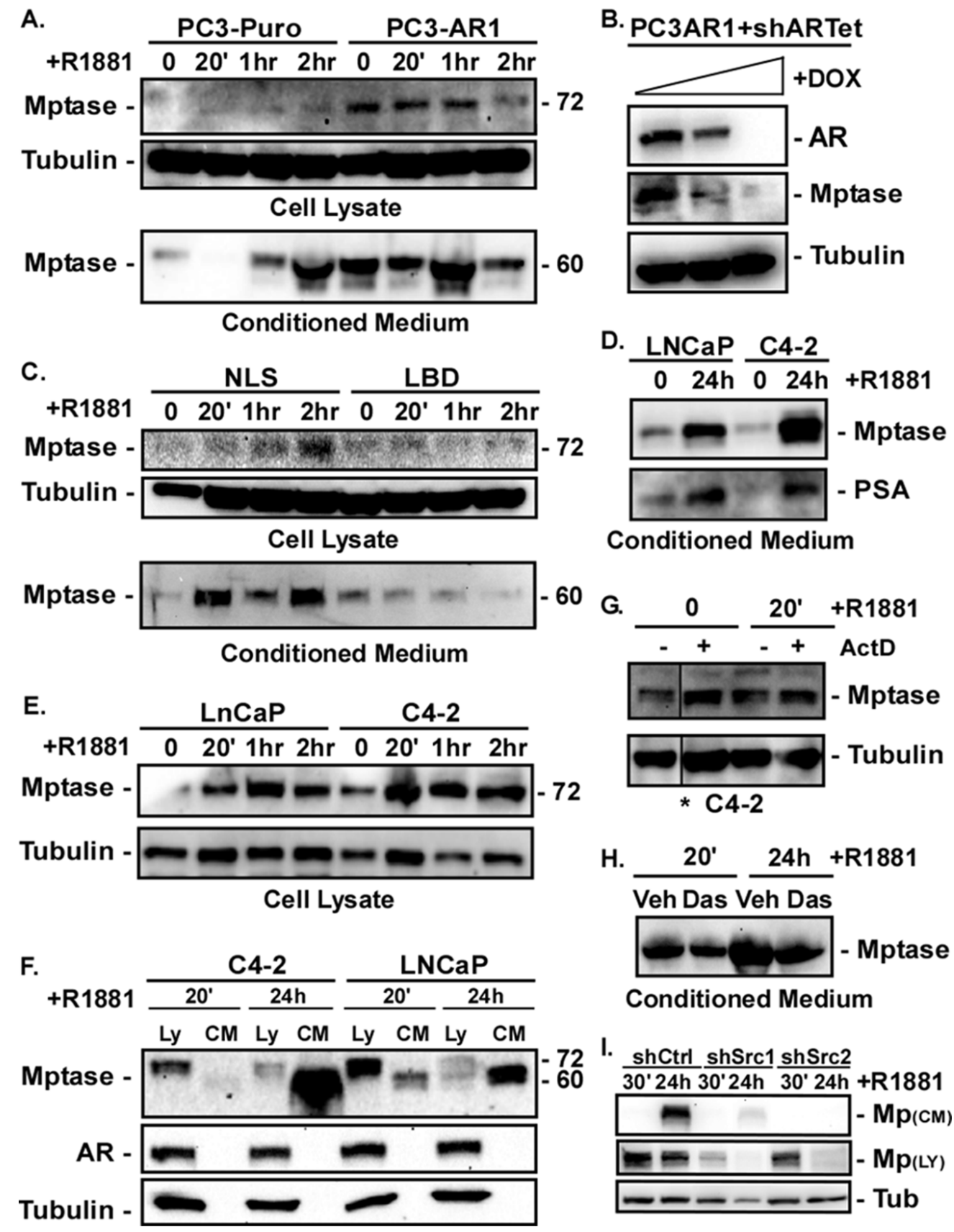
H. 20' $24 \mathrm{~h}+\mathrm{R} 1881$ Veh Das Veh Das Tom - Mptase

\section{Conditioned Medium}

I. shCtrl shSrc1 shSrc2 \begin{aligned} \hline $30^{\prime} 24 \mathrm{~h} 30^{\prime} 24 \mathrm{~h} 30^{\prime} 24 \mathrm{~h} & +\mathrm{R} 1881 \\ - & -\mathrm{Mp}_{(\mathrm{CM})} \\$\hline & $-\mathrm{Mp}_{(\mathrm{LY})} \\ - & -\end{aligned}$

Figure 4: AR stimulates Matriptase activation and extracellular shedding in a non-nuclear fashion. (A) PC3-Puro or PC3-AR clones were stimulated with $10 \mathrm{nM} \mathrm{R} 1881$ for $0,20,60,120$ minutes $\left(0,20^{\prime}, 1 \mathrm{hr}, 2 \mathrm{hr}\right)$. Levels of active Matriptase in cell lysates and secreted into the conditioned medium were measured by immunoblotting. (B) PC3-AR cells stabling expressing a Tet-inducible AR shRNA (shARTet) were stimulated with $100-400 \mu \mathrm{g} / \mathrm{ml}$ doxycycline for 24 hours and the levels of AR and active Matriptase in the cell lysate measured by immunoblotting. (C) PC3 cells expressing AR $\triangle$ NLS or AR $\triangle$ LBD were stimulated with $10 \mathrm{nM}$ R1881 for 0, 20, 60, 120 minutes $\left(0,20^{\prime}, 1 \mathrm{hr}, 2 \mathrm{hr}\right)$. Levels of active Matriptase in cell lysates and secreted into the conditioned medium were measured by immunoblotting. (D, E) LNCaP or C4-2 cells were stimulated with $10 \mathrm{nM} \mathrm{R} 1881$ for (D) 24 hours or (E) 0, 20, 60, 120 minutes (0, 20', $1 \mathrm{hr}, 2 \mathrm{hr}$ ). (D) Active Matriptase secreted into the conditioned medium or (E) in cell lysates was measured by immunoblotting. (F) Active Matriptase in the lysates (Ly) or conditioned medium (CM) from LNCaP or C4-2 cells stimulated with 10 nM R1881 for 20 minutes (20') or 24 hours $(24 \mathrm{~h}$ ) was measured by immunoblotting. (G) C4-2 cells were stimulated with ethanol (0) or $10 \mathrm{nM}$ R1881 for 20 minutes $\left(20^{\prime}\right)$ after 2 hours of pretreatment with vehicle $(-)$ or $10 \mu \mathrm{g} / \mathrm{ml}$ Actinomycin D (+). Active Matriptase in the cell lysate was measured by immunoblotting. *All samples were run on the same gel, but image was cut to rearrange lanes. (H) C4-2 cells treated with vehicle (Veh) or $10 \mathrm{nM}$ dasatinib for 24 hours were then stimulated with $10 \mathrm{nM} \mathrm{R} 1881$ for 20 minutes $\left(20^{\prime}\right)$ or 24 hours (24 h). Active Matriptase in the conditioned medium was measured by immunoblotting. (I) C4-2 cells expressing control shRNA (shCtrl) or two different Src shRNAs (shSrc) were stimulated with $10 \mathrm{nM} \mathrm{R} 1881$ for 30 minutes $\left(30^{\prime}\right)$ or 24 hours $(24 \mathrm{~h})$ and the levels of Matriptase in conditioned medium and cell lysates measured by immunoblotting. 
tyrosine phosphorylation of cleaved CDCP1 (Figure 5A). Inhibition of AR or Src expression with siRNA, or treatment with the Src inhibitor dasatinib prevented cleavage and tyrosine phosphorylation of the cleaved fragment (Figure 5A). While dasatinib can target other Src-related tyrosine kinases as well as some receptor kinases, it abrogated generation of the CDCP1 cleavage product $(72 \mathrm{kDa})$ and its phosphorylation to a similar extent as the Src siRNA (Figure 5A). Conversely, treatment of C4-2 cells with R1881 rapidly increased CDCP1 cleavage and tyrosine phosphorylation (not shown). However, inhibition of CDCP1 expression (Figure 5B) had no effect on invasion (Figure 5C). Although Src activation by $\mathrm{AR}$ is able to induce cleavage and phosphorylation of CDCP1, this target is not critical for AR-dependent invasion of Matrigel.

\section{Matriptase is required for AR-dependent invasion}

To assess whether Matriptase is required for increased invasion induced by AR signaling, its expression was suppressed by siRNA in PC3-AR cells and the effect on Matrigel invasion evaluated. Inhibition of Matriptase expression (Figure 6A) decreased invasion 3-fold (Figure 6B). Conditioned medium from PC3-AR cells containing cleaved Matriptase was sufficient to increase the invasiveness of androgen-deprived C4-2 cells 3-fold relative to untreated cells (Figure 6C). Conversely, depletion of shed Matriptase from the PC3-AR cell conditioned medium reduced C4-2 cell invasion 5-fold (Figure 6D). Thus, shed Matriptase is required and sufficient to promote Matrigel invasion of prostate tumor cells.

\section{DISCUSSION}

In addition to its role in regulating gene transcription in the nucleus, AR like other steroid receptors rapidly activates signal transduction pathways in the cytoplasm. Pathways reported to be activated by nongenomic AR signaling include MAPK, PI-3K, EGFR, and Src [16, 17, 43, 44]. Functionally, these pathways were linked to AR-dependent increases in cell proliferation. In this study, we demonstrate for the first time that AR stimulates integrin-dependent prostate cancer invasion by stimulating Src activity through a ligand-dependent but non-nuclear mechanism. Src in turn stimulates rapid cell-associated Matriptase cleavage and its extracellular shedding, which is required for laminin matrix-dependent invasion.

We employed several different prostate cancer cell lines to demonstrate the universality of the nongenomic AR/Src invasion pathway. The first model made use of PC3 cells engineered to express AR (PC3-AR). We previously demonstrated that PC3-AR cells display constitutive AR transcriptional activity as measured by nuclear AR localization and elevated PSA and TMPRSS2 expression in the absence of androgen [29]. Cells were always maintained at low passage and grown only in charcoal stripped serum for cultivation to prevent over activation of AR, which often inhibits proliferation as seen in other PC3-AR models. The level of AR expression in these clones was not excessive; comparable to that seen in LNCaP cells as demonstrated previously [29]. LNCaP, C4-2, and VCaP cells that express endogenous $\mathrm{AR}$ require androgen to be transcriptionally activated. The advantage of the PC3-AR model is that we were able to express a mutant of AR that is defective in nuclear localization, and thus lacks transcriptional activity, or is defective in ligand binding [29, 31, 32]. Thus, we were able to demonstrate that Src and Matriptase activation and shedding occurs via a nongenomic mechanism, i.e. independent of AR nuclear activity. Additional support for the nongenomic mechanism was afforded by the fact that androgen stimulation of PC3 control cells that do not express detectable levels of AR also stimulates cleaved Matriptase shedding; consistent with the observation that low levels of AR that are not sufficient to activate classical transcriptional responses, are sufficient to activate cytoplasmic signal transduction pathways. We used the androgen responsive lines to demonstrate the $\mathrm{AR} / \mathrm{Src}$ invasion pathway is also active in androgenresponsive cells. The nongenomic aspects of AR, Src, and Matriptase activation in these cells were evidenced by a rapid response occurring independently of new mRNA synthesis. The lack of dependence of this invasion pathway on the AR-dependent integrin $\alpha 6$ pathway, which is transcriptionally activated by AR [29], further indirectly supports a nongenomic mechanism.

Depending on the model being examined, the ability of steroid receptors to activate nongenomic signaling may or may not be ligand dependent. Our data demonstrating that Casodex and RU486, ligand antagonists, block invasion and Src activation support the conclusion that the $\mathrm{AR} / \mathrm{Src}$ invasion pathway is ligand dependent. Therefore, we expected the cells expressing the AR ligand binding mutant (LBD) to be neither invasive nor to activate Src. Contrary to expectations, Src was constitutively activated and the cells were highly invasive. However, the PC3ARLBD cells did not behave like any of the other cell lines in that their invasive activity was not dependent on Src, even though Src activity was elevated; nor did they induce Matriptase activation. Our finding that addition of cleaved and thus activated Matriptase, generated by AR/ Src signaling, exogenously to non-stimulated cells was sufficient to increase invasion, indicates that the primary target of AR/Src signaling in invasion is Matriptase. Thus in the PC3AR-LBD cells, the failure to activate Matriptase in spite of active Src, suggests it is Matriptase activation that is sensitive to ligand binding. It further suggests that depending on whether Src is activated through a liganddependent or -independent mechanism may determine which downstream targets are affected and the biological outcome. 
A.

\section{Sc sAR sSr Das Sc sAR sSr Das}
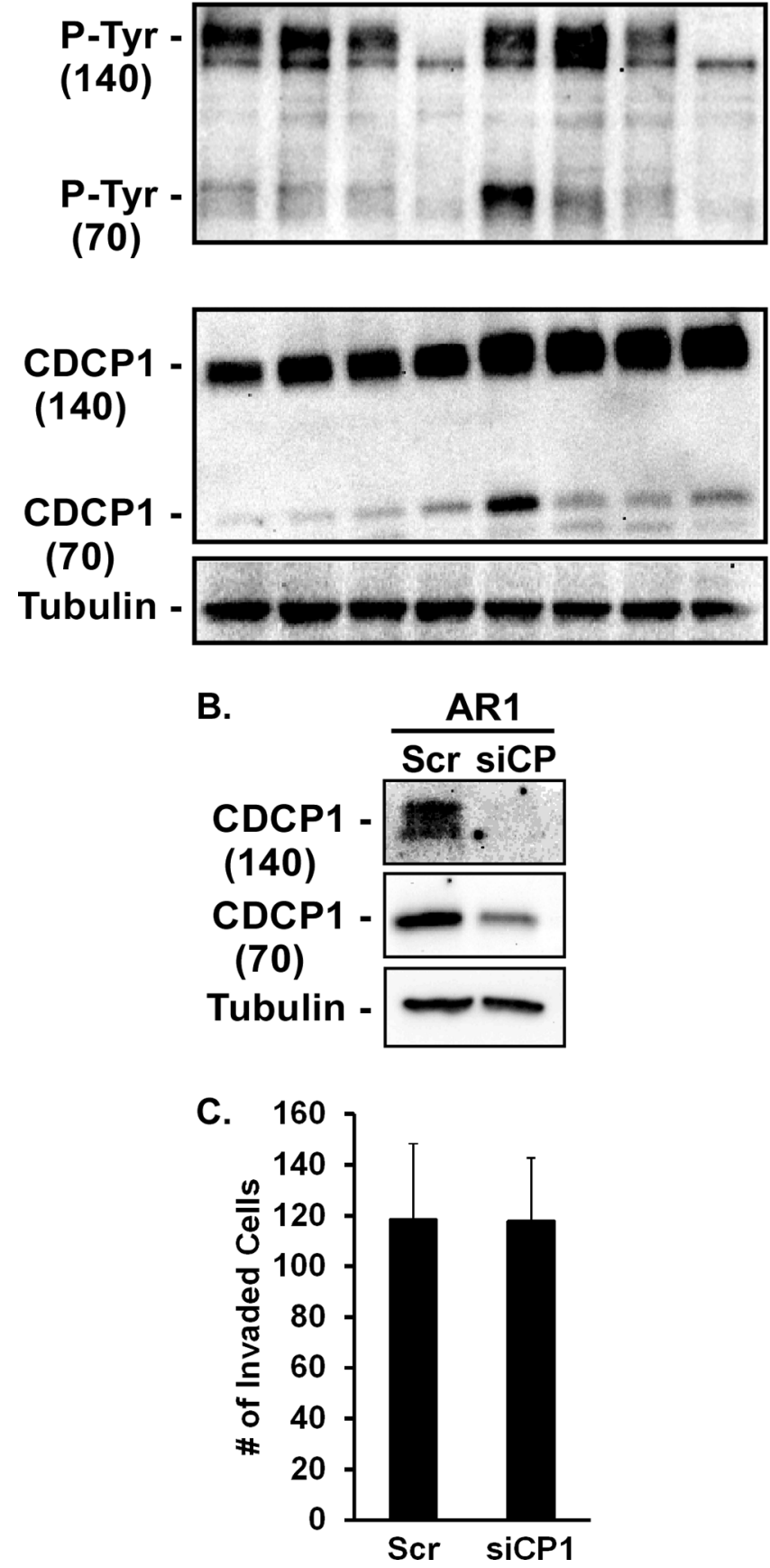

Figure 5: CDCP1 activity is regulated by AR and Src. (A) PC3-Puro (PP) or PC3-AR cells were treated with scrambled siRNA (Sc), AR- or Src-specific siRNA (sAR, sSr), or $10 \mathrm{nM}$ dasatinib for 24 hours. Tyrosine phosphorylation and expression of full length $(140 \mathrm{kDa})$ and cleaved $(70 \mathrm{kDa}) \mathrm{CDCP} 1$ from immunoprecipitates were measured by immunoblotting with anti-phosphotyrosine antibody or CDCP1 antibody respectively. (B, C) PC3-AR cells were treated with scrambled siRNA (Scr) or CDCP1-specific siRNA (siCP1).

(B) CDCP1 expression was measured by immunoblotting and (C) Matrigel invasion was quantified.

Our data strongly support a nongenomic mechanism for Matriptase activation. It occurs in the absence of nuclear function and in the absence of new mRNA synthesis. A previous study demonstrated that androgen induces Matriptase activation and shedding in LNCaP cells 6-24 hours after stimulation [45]. In that study, Matriptase mRNA was elevated 24 hours after androgen stimulation and was dependent on new mRNA and protein synthesis at that time point. Combining those findings with ours, we envision a model whereby nongenomic AR 

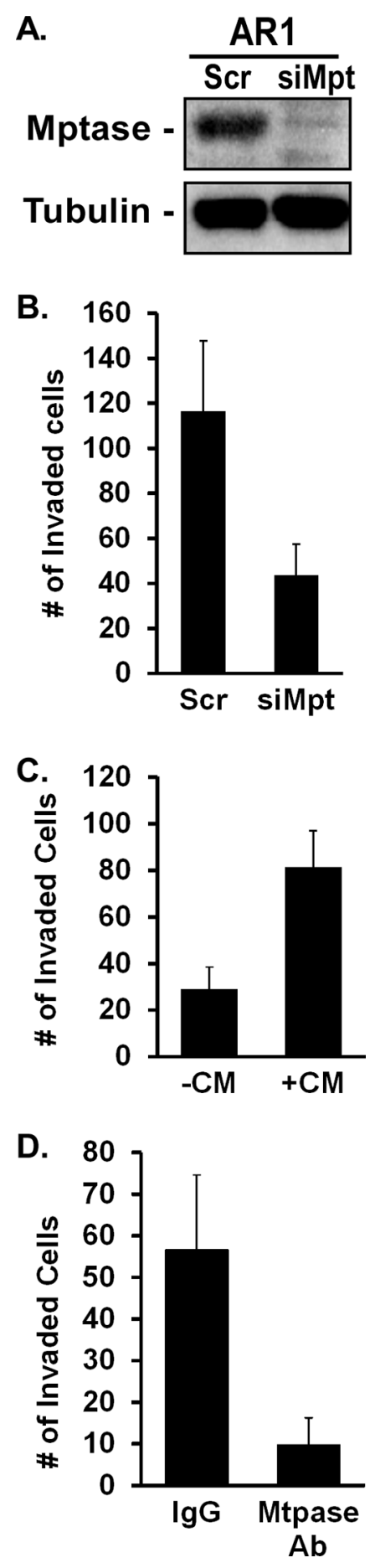

Figure 6: Matriptase, but not CDCP1, promotes AR-dependent invasion. (A, B) PC3-AR cells were treated with scrambled siRNA (Scr) or Matriptase-specific siRNA (siMpt). (A) Matriptase expression was measured by immunoblotting and (B) Matrigel invasion was quantified. (C, D) Conditioned medium $(+\mathrm{CM})$ containing Matriptase from unstimulated PC3-AR cells or BSA $(-\mathrm{CM})(\mathrm{C})$ was added to unstimulated C4-2 cells or (D) CM was first depleted of Matriptase with specific antibody (Mtpase Ab) or IgG and the supernatant added to unstimulated C4-2 cells. The ability of untreated or treated C4-2 cells to invade Matrigel was quantified.

signaling to Src, either through direct phosphorylation of Matriptase or indirectly through an associated molecule, triggers an initial activation of the autocatalytic cleavage of Matriptase between 20 minutes and 2 hours. The cellassociated Matriptase diminishes at the same time it appears in abundance in the conditioned medium, over the course of 24 hours (Figure 4F). The cleavage and release of Matriptase depletes cellular stores, triggering an AR-dependent, but indirect, transcriptional increase in Matriptase mRNA as reported previously [45]. 
To determine additional aspects of the mechanism by which AR/Src signaling to Matriptase increases invasion, we interrogated CDCP1, a known integrin regulator and Src and Matriptase substrate [38-42]. While CDCP1 cleavage and phosphorylation was dependent on AR and Src, it was not required for AR-dependent invasion. Clinically, this is important because CDCP1 expression is often elevated in primary cancers and prognostic of poor outcome and survival [46]; however, recent evidence indicates its expression actually decreases within metastatic prostate cancer lesions (B. Knudsen, personal communication). While, CDCP1 may be necessary in vivo for initial metastatic dissemination [47], the dependence on CDCP1 in late stage disease may decrease. It is also possible that CDCP1 dependency is specific to a subset of integrin/matrix interactions.

While enzalutamide can extend patient survival for 6 months, it is far from curative [48]. One mechanism proposed for enzalutamide resistance is increased Src activation [18]. Whether this is mediated through cytoplasmic-localized AR, AR variants that arise during enzalutamide resistance [49], or by some other mechanism remains to be determined. Our data further indicate that when Src is activated in resistant disease it could activate Matriptase. In laminin-enriched tumor microenvironments, such as that found in the bone and lymph nodes [50], Matriptase activation may enhance metastatic spread and could serve as an ideal therapeutic target in resistant disease.

\section{MATERIALS AND METHODS}

\section{Cell culture}

The prostate tumor cell lines PC3, LNCaP, and $\mathrm{VCaP}$, were purchased from American Type Culture Collection. C4-2 cells were obtained from Dr. Robert Sikes, University of Delaware [51]. PC3 cells were grown in $\mathrm{F}-12 \mathrm{~K}$ media supplemented with $10 \%$ charcoal-stripped and charcoal-stripped fetal bovine serum (CSS), $2 \mathrm{mM}$ glutamine, $50 \mathrm{U}$ penicillin, and $50 \mu \mathrm{g} / \mathrm{ml}$ streptomycin. LNCaP, VCaP, and C4-2 cells were grown in RPMI 1640 media (Invitrogen) supplemented with 10\% fetal bovine serum, $2 \mathrm{mM}$ glutamine, $50 \mathrm{U}$ penicillin, $50 \mu \mathrm{g} /$ $\mathrm{ml}$ streptomycin, $0.225 \%$ glucose, $10 \mathrm{mM}$ HEPES, and $1 \mathrm{mM}$ sodium pyruvate. For experiments, LNCaP, VCaP, and C4-2 cells were seeded on laminin (Millipore) and grown in phenol-red free media and $0.1 \%$ CSS for 24 hours before and throughout the experiment. All cells were grown at $37^{\circ} \mathrm{C}$ in $5 \% \mathrm{CO}_{2}$.

\section{DNA constructs and cell lines}

Stable clonal isolates of PC3 cells expressing empty vectors, PC3-Puro and pLKO.1, or wild type or mutant

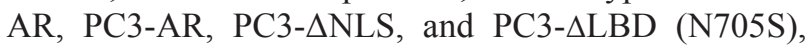
were generated by infecting cells with retroviruses or lentiviruses as described previously [29]. PC3-AR TetON shRNA clones were generated by using pLKO-TetON vector (Novartis) that contained a single AR shRNA, 5'-CCGGCCTGCTAATCAAGTCACACATCTCGAGA TGTGTGACTTGATTAGCAGGTTTTT-3', purchased from Open Biosystems and cloned upstream of the $\mathrm{H} 1 /$ TO promoter as described [52, 53]. Src shRNAs, shSrc1: 5'-GACAGACCTGTCCTTCAAGAA-3' and shSrc2: 5'-GCGGCTCCAGATTGTCAACAA-3' in TRC pLKO vector were purchased from Sigma. The AR Tet-ON and Src shRNA plasmids were sequence validated and packaged into lentiviruses using 293FT cells (Invitrogen). PC3-AR cells were infected with Tet-ON-ARshRNA or Src shRNA lentiviruses and individual clones were selected using 1-3 $\mu \mathrm{g} / \mathrm{ml}$ puromycin.

\section{siRNA transfections}

A pool of four small interfering RNAs (siRNA) against androgen receptor (siGENOME SMARTpool), integrin $\alpha 6$ (ON-TARGETplus SMARTpool); integrin a3 (ON-TATRGETplus SMARTpool); Src (ONTARGETplus SMARTpool); CDCP1 (ON-TATRGETplus SMARTpool), or a non-targeting sequence were purchased from Dharmacon. Matriptase-specific siRNA was obtained from Santa Cruz Biotechnology, Inc. Serumdeprived sub-confluent cells were transfected with siRNA using siLentFect lipid reagent (Bio-Rad) and OptiMEM (Invitrogen) medium following manufacturer's directions. The medium was changed 16 hours after siRNA transfection. All pools were titrated to determine the lowest optimal concentration for inhibition of protein expression by immunoblotting 72 hours after transfection.

\section{Drug treatments}

Mifrepristone (RU486) was purchased from Tocris Bioscience (Ellisville, MO). Dasatinib was a gift from Dr. Matt Steensma (Van Andel Research Institute). Bicalutamide (Casodex) was purchased from Enzo Life Science (Farmingdale, NY). Each drug was diluted into ethanol and used at a final concentration of $10 \mathrm{nM}$. Metribolone (R1881) was purchased from PerkinElmer (Boston, MA). R1881 was diluted into ethanol and then into phenol red free media and used at a final concentration of $10 \mathrm{nM}$ in all experiments. Actinomycin D was purchased from Calbiochem and reconstituted in DMSO at a concentration of $10 \mu \mathrm{g} / \mathrm{mL}$. For R1881 treatments, cells were starved 24 hours in $0.1 \%$ charcoal-stripped serum (CSS) prior to stimulation. Inhibitors were added during the starvation period and maintained during androgen stimulation.

\section{Immunoblotting}

Total whole cell lysates were prepared for immunoblotting as previously described $[30,54]$. Briefly, cells were lysed on ice with MAPK lysis buffer (50 mM 
Tris pH 7.5, $0.5 \mathrm{mM}$ EDTA, $50 \mathrm{mM} \mathrm{NaF}, 100 \mathrm{mM} \mathrm{NaCl}$, $50 \mathrm{mM} \beta$-glycerophosphate, $5 \mathrm{mM}$ sodium pyrophosphate, 1\% Triton-X100, $1 \mathrm{mM} \mathrm{Na} \mathrm{VO}_{4}, 1 \mathrm{mM}$ PMSF, $5 \mu \mathrm{g} / \mathrm{ml}$ leupeptin, $5 \mu \mathrm{g} / \mathrm{ml}$ pepstatin, $10 \mu \mathrm{g} / \mathrm{ml}$ aprotinin, $1 \mathrm{mM}$ benzamide) or RIPA (10 mM Tris $\mathrm{pH} 7.2,158 \mathrm{mM} \mathrm{NaCl}$, $1 \mathrm{mM}$ EDTA, $0.1 \%$ SDS, $1 \%$ NaDOC, 1\% Triton-X100, $1 \mathrm{mM} \mathrm{Na} \mathrm{VO}_{4}, 1 \mathrm{mM}$ PMSF, $100 \mathrm{U} / \mathrm{ml}$ aprotinin, $10 \mu \mathrm{g} / \mathrm{ml}$ pepstatin and $10 \mu \mathrm{g} / \mathrm{ml}$ leupeptin). For immunoblotting, 40-65 $\mu \mathrm{g}$ of total cell lysates in 2X SDS sample buffer were boiled for 5 minutes and run on SDS polyacrylamide gels following standard SDS-PAGE protocols, then transferred to PVDF membranes. Membranes were blocked in 5\% BSA in TBST for two hours at room temperature, and then were probed with primary antibody for two hours at room temperature. Signal was detected, after incubation with horseradish peroxide-conjugated secondary antibodies (Bio-Rad) in 5\% BSA in TBST for 1 hour at room temperature, by chemiluminescence with a CCD camera in a Bio-Rad Chemi-Doc Imaging System using Quantity One software v4.5.2 (Bio-Rad).

Primary antibodies were as follows: anti-AR monoclonal antibody (Santa Cruz Biotechnology); anti-Bcl-xL polyclonal antibody (Cell Signaling Technologies); antiMatriptase polyclonal antibody (Bethyl Laboratories); antiphospho-[ $\left.\mathrm{Y}^{416}\right]-$ Src polyclonal antibody (Invitrogen); anti-Src monoclonal antibody (Src 327) [55]; anti-CDCP1 polyclonal antibody (Cell Signaling Technologies); and anti-Tubulin monoclonal antibody (Sigma-Aldrich).

\section{Immunoprecipitation}

For detection of phosphorylated CDCP1 and phospho- $\left[\mathrm{Y}^{416}\right]-\mathrm{Src}$, cell lysates were prepared as described above. Protein samples $(500 \mu \mathrm{g})$, in a volume of $500 \mu \mathrm{L}$ of $1 \mathrm{X}$ MAPK buffer, were incubated with $1 \mu \mathrm{g}$ of mouse monoclonal anti-Src antibody [55] or anti-CDCP1 (Cell Signaling Technologies) overnight at $4{ }^{\circ} \mathrm{C}$. Proteinantibody complex was precipitated with protein $\mathrm{G}$ or protein A beads (Thermo Scientific) respectively followed by immunoblotting with rabbit anti-phospho-[ $\left.\mathrm{Y}^{416}\right]-\mathrm{Src}$ antibody (Invitrogen) or mouse 4G10 anti-phosphotyrosine antibody (Millipore) as described above.

\section{Immunofluorescence}

Cells were fixed with $4 \%$ paraformaldehyde in PBS at $4{ }^{\circ} \mathrm{C}$ for twenty minutes and permeabilized for ten minutes with TBS (10 mM Tris, $\mathrm{pH} 8.0,150 \mathrm{mM}$ $\mathrm{NaCl})+0.5 \%$ TritonX-100 at room temperature. Cells were then blocked with $2 \% \mathrm{BSA}$ in TBS $+0.1 \%$ Triton $\mathrm{X}-100$ for twenty minutes at room temperature before incubation with vinculin antibody (Sigma) and Alexafluor 546-Phalloidin (Molecular Probes, Invitrogen) for one hour. Cells were incubated with goat anti-mouse Alexa Flour-488 secondary antibody for one hour at room temperature. DNA was visualized by staining with
Hoechst 33258 for 10 minutes at room temperature. Cells were washed four times with TBS $+0.1 \%$ TritonX-100 over ten minutes between all steps. Epifluorescent images were acquired on a Nikon Eclipse TE300 fluorescence microscope using OpenLab v5.5.0 image analysis software (Improvision).

\section{Migration assays}

Cell migration was measured using the modified Boyden chamber assay. Cells $\left(5 \times 10^{4}\right)$ were suspended in the upper well of the $8.0 \mu \mathrm{m}$ pore size polyethylene terephthalate membrane culture inserts for (BD Biosciences) in which the bottom membrane was precoated with $1 \mu \mathrm{M}$ laminin. The lower and upper chambers were filled with $400 \mu \mathrm{L}$ phenol-red and serum-free DMEM. After 6 hours of incubation, the culture inserts were removed and washed with $1 \mathrm{X}$ PBS. Cells that had migrated to the lower membrane surface were stained with Crystal Violet (Millipore) and counted under a microscope in five random fields per insert in triplicate.

\section{Matrigel invasion assays}

Serum-starved sub-confluent cells $\left(6.25 \times 10^{4}\right)$ were suspended in the upper well of the $8.0 \mu \mathrm{m}$ pore size Matrigel membrane culture inserts (BD Biosciences) in which the bottom membrane was pre-coated with $1 \mu \mathrm{M}$ laminin. The upper and lower chambers were filled with $400 \mu \mathrm{L}$ phenol-red and serum-free DMEM. After 72 hour incubation, the culture inserts were removed and washed once with $1 \mathrm{X}$ PBS. Cells that invaded through Matrigel to the lower membrane surface were stained with Crystal Violet (Millipore) and counted under a microscope in five random fields per insert in triplicate.

\section{Isolation of conditioned medium}

To examine Matriptase shedding into the medium, cells were washed 2 times with PBS and placed in serumfree medium for 24 hours prior to R1881 stimulation. $10-15 \mathrm{~mL}$ of medium was collected on ice from the plates and loaded into Amicon Ultra-15 centrifugal filter units (Millipore). The Amicon filter tubes were centrifuged at $4000 \times \mathrm{g}$ for 30 minutes at $4^{\circ} \mathrm{C}$. Concentrated medium was collected and subjected to SDS PAGE and transferred to PVDF membrane for immunoblotting. Protein loading was normalized to total cell number.

\section{ACKNOWLEDGMENTS}

Research for this study was supported by the National Cancer Institute of the National Institutes of Health under award number R01CA154835 (V.V.S., E.A.N.) and NCI Diversity Supplement (J.C.Z.) and by the Van 
Andel Research Institute (VARI). We thank Drs. C.J. Logothetis and B.S. Knudsen for helpful discussions on the clinical importance of these studies. The C4-2 cells were generously supplied by Dr. Robert Sikes, University of Delaware, and Dasatinib was a gift from Dr. Matt Steensma, VARI. Special thanks to the Center for Skeletal Disease and Tumor Microenvironment for their feedback. The content is solely the responsibility of the authors and does not necessarily represent the official views of the National Institutes of Health.

\section{CONFLICT OF INTEREST}

The authors declare no conflict of interest.

\section{REFERENCES}

1. Agoulnik IU, Vaid A, Bingman WE 3rd, Erdeme H, Frolov A, Smith CL, Ayala G, Ittmann MM. Weigel Role of SRC-1 in the promotion of prostate cancer cell growth and tumor progression. Cancer Res. 2005; 65:7959-7967.

2. Feldman BJ, Feldman D. The development of androgenindependent prostate cancer. Nat Rev Cancer. 2001; 1: 34-45.

3. Seruga B, Tannock IF. Intermittent androgen blockade should be regarded as standard therapy in prostate cancer. Nat Clin Pract Oncol. 2008; 5:574-576.

4. Yuan X, Cai C, Chen S, Yu Z, Balk SP. Androgen receptor functions in castration-resistant prostate cancer and mechanisms of resistance to new agents targeting the androgen axis. Oncogene. 2014; 33:2815-25.

5. van Soest RJ, van Royen ME, de Morree ES, Moll JM, Teubel W, Wiemer EA, Mathijssen RH, de Wit R, van Weerden WM. Cross-resistance between taxanes and new hormonal agents abiraterone and enzalutamide may affect drug sequence choices in metastatic castration-resistant prostate cancer. Eur J Cancer. 2013; 49:3821-3830.

6. Chen Y, Clegg NJ, Scher HI. Anti-androgens and androgendepleting therapies in prostate cancer: new agents for an established target. Lancet Oncol. 2009; 10:981-991.

7. Tran C, Ouk S, Clegg NJ, Chen Y, Watson PA, Arora V, Wongvipat J, Smith-Jones PM, Yoo D, Kwon A, Wasielewska T, Welsbie D, Chen CD, Higano CS, Beer TM, Hung DT, et al. Development of a second-generation antiandrogen for treatment of advanced prostate cancer. Science. 2009; 324:787-790.

8. Castoria G, Lombardi M, Barone MV, Bilancio A, Di Domenico M, De Falco A, Varricchio L, Bottero D, Nanayakkara M, Migliaccio A, Auricchio F. Rapid signalling pathway activation by androgens in epithelial and stromal cells. Steroids. 2004; 69:517-522.

9. Watson CS, Gametchu B. Membrane-initiated steroid actions and the proteins that mediate them. Proc Soc Exp Biol Med. 1999; 220:9-19.
10. McEwen BS, Alves SE. Estrogen actions in the central nervous system. Endocr Rev. 1999; 20:279-307.

11. Arnold JT, Isaacs JT. Mechanisms involved in the progression of androgen-independent prostate cancers: it is not only the cancer cell's fault. Endocr Relat Cancer. 2002; 9: $61-73$.

12. Wehling M. Specific, nongenomic actions of steroid hormones. Annu Rev Physiol. 1997; 59:365-393.

13. Revelli A, Massobrio M, Tesarik J. Nongenomic actions of steroid hormones in reproductive tissues. Endocr Rev. 1998; 19:3-17.

14. Boonyaratanakornkit V, Scott MP, Ribon V, Sherman L, Anderson SM, Maller JL, Miller WT, Edwards DP. Progesterone receptor contains a proline-rich motif that directly interacts with $\mathrm{SH} 3$ domains and activates c-Src family tyrosine kinases. Mol Cell. 2001; 8:269-280.

15. Migliaccio A, Castoria G, Di Domenico M, de Falco A, Bilancio A, Lombardi M, Barone MV, Ametrano D, Zannini MS, Abbondanza C, Auricchio F. Steroid-induced androgen receptor-oestradiol receptor beta-Src complex triggers prostate cancer cell proliferation. EMBO J. 2000; 19:5406-5417.

16. Sun M, Yang L, Feldman RI, Sun XM, Bhalla KN, Jove R, Nicosia SV, Cheng JQ. Activation of phosphatidylinositol 3-kinase/Akt pathway by androgen through interaction of p85a, androgen receptor, and Src. J Biol Chem. 2003; 278:42992-43000.

17. Zhoul J, Hernandez G, Tu SW, Huang CL, Tseng CP, Hsieh JT. The role of DOC-2/DAB2 in modulating androgen receptor-mediated cell growth via the nongenomic c-Src-mediated pathway in normal prostatic epithelium and cancer. Cancer Res. 2005; 65:9906-9913.

18. Efstathiou E, Titus M, Wen S, Hoang A, Karlou M, Ashe R, Tu SM, Aparicio A, Troncoso P, Mohler J, Logothetis CJ. Molecular characterization of enzalutamide-treated bone metastatic castration-resistant prostate cancer. Eur Urol. $2015 ; 67: 53-60$.

19. Thomas SM, Brugge JS. Cellular functions regulated by Src family kinases. Annu Rev Cell Dev Biol. 1997; 13: 513-609.

20. Yeatman TJ. A renaissance for SRC. Nat Rev Cancer. 2004; 4:470-480.

21. Zhang XH, Wang Q, Gerald W, Hudis CA, Norton L, Smid M, Foekens JA, Massague J. Latent bone metastasis in breast cancer tied to Src-dependent survival signals. Cancer Cell. 2009; 16:67-78.

22. Varkaris A, Katsiampoura AD, Araujo JC, Gallick GE, Corn PG. Src signaling pathways in prostate cancer. Cancer Metastasis Rev. 2014; 33:595-606.

23. Park SI, Zhang J, Phillips KA, Araujo JC, Najjar AM, Volgin AY, Gelovani JG, Kim SJ, Wang Z, Gallick GE. Targeting SRC family kinases inhibits growth and lymph node metastases of prostate cancer in an orthotopic nude mouse model. Cancer Res. 2008; 68:3323-3333. 
24. Migliaccio A, Di Domenico M, Castoria G, de Falco A, Bontempo P, Nola E, Auricchio F. Tyrosine kinase/p21ras/ MAP-kinase pathway activation by estradiol-receptor complex in MCF-7 cells. EMBO J. 1996; 15:1292-1300.

25. Unni E, Sun S, Nan B, McPhaul MJ, Cheskis B, Mancini MA, Marcelli M. Changes in androgen receptor nongenotropic signaling correlate with transition of $\mathrm{LNCaP}$ cells to androgen independence. Cancer Res. 2004; 64: 7156-7168.

26. Chakravarty D, Nair SS, Santhamma B, Nair BC, Wang L, Bandyopadhyay A, Agyin JK, Brann D, Sun LZ, Yeh IT, Lee FY, Tekmal RR, Kumar R, Vadlamudi RK. Extranuclear functions of ER impact invasive migration and metastasis by breast cancer cells. Cancer Res. 2010; 70:4092-4101.

27. Asim M, Siddiqui IA, Hafeez BB, Baniahmad A, Mukhtar H. Src kinase potentiates androgen receptor transactivation function and invasion of androgen-independent prostate cancer C4-2 cells. Oncogene. 2008; 27:3596-3604.

28. Cai H, Babic I, Wei X, Huang J, Witte ON. Invasive prostate carcinoma driven by c-Src and androgen receptor synergy. Cancer Res. 2011; 71:862-872.

29. Lamb LE, Zarif JC, Miranti CK. The androgen receptor induces integrin $\alpha 6 \beta 1$ to promote prostate tumor cell survival via NF-kB and Bcl-xL Independently of PI3K signaling. Cancer Res. 2011; 71:2739-2749.

30. Edick MJ, Tesfay L, Lamb LE, Knudsen BS, Miranti CK. Inhibition of integrin-mediated crosstalk with epidermal growth factor receptor/Erk or Src signaling pathways in autophagic prostate epithelial cells induces caspase-independent death. Mol Biol Cell. 2007; 18:2481-2490.

31. Chen CD, Welsbie DS, Tran C, Baek SH, Chen R, Vessella R, Rosenfeld MG, Sawyers CL. Molecular determinants of resistance to antiandrogen therapy. Nat Med. 2004; 10:33-39.

32. Xin L, Teitell MA, Lawson DA, Kwon A, Mellinghoff IK, Witte ON. Progression of prostate cancer by synergy of AKT with genotropic and nongenotropic actions of the androgen receptor. Proc Natl Acad Sci U S A. 2006; 103:7789-7794.

33. Tripathi M, Potdar AA, Yamashita H, Weidow B, Cummings PT, Kirchhofer D, Quaranta V. Laminin-332 cleavage by matriptase alters motility parameters of prostate cancer cells. Prostate. 2011; 71:184-196.

34. List K, Szabo R, Molinolo A, Nielsen BS, Bugge TH. Delineation of matriptase protein expression by enzymatic gene trapping suggests diverging roles in barrier function, hair formation, and squamous cell carcinogenesis. Am J Pathol. 2006; 168:1513-1525.

35. Uhland K. Matriptase and its putative role in cancer. Cell Mol Life Sci. 2006; 63:2968-2978.

36. Alimirah F, Chen J, Basrawala Z, Xin H, Choubey D. DU145 and PC-3 human prostate cancer cell lines express androgen receptor: implications for the androgen receptor functions and regulation. FEBS Lett. 2006; 580:2294-2300.

37. Culig Z, Klocker H, Eberle J, Kaspar F, Hobisch A, Cronauer MV, Bartsch G. DNA sequence of the androgen receptor in prostatic tumor cell lines and tissue specimens assessed by means of the polymerase chain reaction. Prostate. 1993; 22:11-22.

38. Wortmann A, He Y, Deryugina EI, Quigley JP, Hooper JD. The cell surface glycoprotein CDCP1 in cancer-insights, opportunities, and challenges. IUBMB Life. 2009; 61:723-730.

39. He Y, Wortmann A, Burke LJ, Reid JC, Adams MN, AbdulJabbar I, Quigley JP, Leduc R, Kirchhofer D, Hooper JD. Proteolysis-induced N-terminal ectodomain shedding of the integral membrane glycoprotein CUB domain-containing protein 1 (CDCP1) is accompanied by tyrosine phosphorylation of its C-terminal domain and recruitment of Src and PKCdelta. J Biol Chem. 2010; 285:26162-26173.

40. Casar B, Rimann I, Kato H, Shattil SJ, Quigley JP, Deryugina EI. In vivo cleaved CDCP1 promotes early tumor dissemination via complexing with activated $\beta 1$ integrin and induction of FAK/PI3K/Akt motility signaling. Oncogene. 2014; 33:255-68.

41. Spassov DS, Ahuja D, Wong CH, Moasser MM. The structural features of Trask that mediate its anti-adhesive functions. PLoS One. 2011; 6:e19154.

42. Alvares SM, Dunn CA, Brown TA, Wayner EE, Carter WG. The role of membrane microdomains in transmembrane signaling through the epithelial glycoprotein Gp140/ CDCP1. Biochim Biophys Acta. 2008; 3:486-496.

43. Kang HY, Cho CL, Huang KL, Wang JC, Hu YC, Lin HK, Chang C, Huang KE. Nongenomic androgen activation of phosphatidylinositol 3-kinase/Akt signaling pathway in MC3T3-E1 osteoblasts. J Bone Miner Res. 2004; 19:1181-1190.

44. Sen A, O’Malley K, Wang Z, Raj GV, Defranco DB, Hammes SR. Paxillin regulates androgen- and epidermal growth factor-induced MAPK signaling and cell proliferation in prostate cancer cells. J Biol Chem. 2010; 285:28787-28795.

45. Kiyomiya K, Lee MS, Tseng IC, Zuo H, Barndt RJ, Johnson MD, Dickson RB, Lin CY. Matriptase activation and shedding with HAI-1 is induced by steroid sex hormones in human prostate cancer cells, but not in breast cancer cells. Am J Physiol Cell Physiol. 2006; 291:C40-49.

46. Ikeda J, Oda T, Inoue M, Uekita T, Sakai R, Okumura M, Aozasa K, Morii E. Expression of CUB domain containing protein (CDCP1) is correlated with prognosis and survival of patients with adenocarcinoma of lung. Cancer Sci. 2009; 100:429-433.

47. Deryugina EI, Conn EM, Wortmann A, Partridge JJ, Kupriyanova TA, Ardi VC, Hooper JD, Quigley JP. Functional role of cell surface CUB domain-containing protein 1 in tumor cell dissemination. Mol Cancer Res. 2009; 7:1197-1211. 
48. Sternberg CN, de Bono JS, Chi KN, Fizazi K, Mulders P, Cerbone L, Hirmand M, Forer D, Scher HI. Improved outcomes in elderly patients with metastatic castration-resistant prostate cancer treated with the androgen receptor inhibitor enzalutamide: results from the phase III AFFIRM trial. Ann Oncol. 2014; 25:429-434.

49. Claessens F, Helsen C, Prekovic S, Van den Broeck T, Spans L, Van Poppel H, Joniau S. Emerging mechanisms of enzalutamide resistance in prostate cancer. Nat Rev Urol. 2014; 11:712-716.

50. Gu YC, Kortesmaa J, Tryggvason K, Persson J, Ekblom P, Jacobsen SE, Ekblom M. Laminin isoform-specific promotion of adhesion and migration of human bone marrow progenitor cells. Blood. 2003; 101:877-885.

51. Thalmann GN, Sikes RA, Wu TT, Degeorges A, Chang SM, Ozen M, Pathak S, Chung LW. LNCaP progression model of human prostate cancer: androgen-independence and osseous metastasis. Prostate 2000; 44:91-103 Jul 101;144.

52. Wee S, Wiederschain D, Maira SM, Loo A, Miller C, deBeaumont R, Stegmeier F, Yao YM, Lengauer C. PTENdeficient cancers depend on PIK3CB. Proc Natl Acad Sci U S A. 2008; 105:13057-13062.

53. Wiederschain D, Wee S, Chen L, Loo A, Yang G, Huang A, Chen Y, Caponigro G, Yao YM, Lengauer C, Sellers WR, Benson JD. Single-vector inducible lentiviral RNAi system for oncology target validation. Cell Cycle. 2009; 8:498-504.

54. Miranti CK. Application of cell adhesion to study signaling networks. Methods Cell Biol. 2002; 69:359-383.

55. Lipsich L, Lewis A, Brugge J. Isolation of monoclonal antibodies that recognize the transforming proteins of avian sarcoma viruses. J Virol. 1983; 48:352-360. 